\title{
Antibacterial kinetics and phylogenetic analysis of Aloe vera plants
}

Paul Akinduti ${ }^{1 *(D)}$, Yemisi D. Obafemi ${ }^{1}$, Patrick O. Isibor ${ }^{2}$, Rapheal Ishola ${ }^{3}$, Frank E. Ahuekwe ${ }^{1}$, O. A. Ayodele ${ }^{4}$, O. S. Oduleye ${ }^{5}$, Olubukola Oziegbe ${ }^{1}$, O. M. Onagbesan ${ }^{6}$

${ }^{1}$ Department of Biological Sciences, Microbiology Unit, Covenant University, Ota, Ogun State, Nigeria; ${ }^{2}$ Department of Biological Sciences, Applied Biology and Biotechnology Unit, Covenant University, Ota, Ogun State, Nigeria; ${ }^{3}$ Department of Medical Microbiology and Parasitology, Olabisi Onabanjo University, Sagamu Campus, Ogun State, Nigeria; ${ }^{4}$ Department of Medical Microbiology, University College Hospital, Ibadan, Nigeria; ${ }^{5}$ Department of Science Laboratory Technology, Microbiology Unit, D.S Adegbenro ICT Polytechnic, Itori, Ewekoro, Nigeria; ${ }^{6}$ Department of Animal Physiology, Federal University of Agriculture, Abeokuta, Nigeria

Edited by: Slavica Hristomanova-Mitkovska Citation: Akinduti P, Obafemi YD, Isibor PO, Ishola R, Ahuekwe $F E$, Ayodele OA, Oduleye OS, Oziegbe $O$, analysis of Aloe vera plants. Open Access Maced J Med Sci. 2021 Nov 13; 9(A):946-954 https://doi.org/10.3889/oamims.2021.652 Keywords: Aloe vera; Sap; Resistant; Diversity

Correspondence: Paukind antibacteria *Correspondence: Paul Akinduti, Microbiology Unit, Department of Biological Sciences, Covenant University,

E-mail: pari Received: 04-Jun-202 Received: 04-Jun-2021 Accepted: 03-Nov-2021 Copyright: ๑ 2021 Paul Akinduti, Yemisi D. Obafemi, Patrick O. Isibor, Rapheal Ishola, Frank E. Ahuekwe, O. A. Ayodele,

O. S. Oduleye, Olubukola Oziegbe, O. M. Onagbesan Funding: Publication was supported by the CUCRID, Covenant University, Ota, Nigeria. The afore-mentioned support agents had no role in study design, data collection and analysis, interpretation

of data, decision to publish, or preparation of th

Competing Interests: The authors have declared that no

Open Access: This is an open-access article istributed under the terms of the Creative Commons Attribution-NonCommercial 4.0 International License
(CC BY-NC 4.0)

\section{Abstract}

BACKGROUND: Uncontrolled use of antibiotics has resulted in the emergence of resistant bacteria. It has necessitated the evaluation of antibacterial activities and phylo-diversity of Aloe vera (also called Aloe barbadensis) plants as antimicrobial agent in Nigeria.

METHODS: Biotyped enteric bacilli of 251 strains obtained from fecal samples of patients with various gastrointestinal complications are profiled for antibiogram. Resistant biotypes were assayed for susceptibility to A. vera latex and further evaluated for time-kill kinetics and phylo-diversity.

RESULTS: More than $30 \%$ of enteric bacilli, including Citrobacter freundii, Escherichia coli, and Proteus mirabilis were resistant to cotrimoxazole, ciprofloxacin, and tetracycline, respectively, at minimum inhibitory concentration $(\mathrm{MIC})>16 \mu \mathrm{g} / \mathrm{ml}(\mathrm{p}=0.004)$. A. vera latex significantly inhibited $39.5 \%$ resistant enteric biotypes with a significant average reduction of the viable count at $1 \times \mathrm{MIC}$ and $2 \times \mathrm{MIC}$ to $<3.0 \mathrm{Log} 10 \mathrm{CFU} / \mathrm{mL}$ after $24 \mathrm{~h}$. Flavonoids, alkaloids, terpenoids, and anthraquinine in anti-enteric sap significantly correlated and regressed with antibacterial activity $(p<$ 0.05), while two of the antimicrobial A. vera plants showed phylogenetic relatedness with other homologous.

CONCLUSION: Antibacteria efficacy of some Nigerian A. vera latex could provide alternative therapy, while its phylodiversity and genomic profiling would offer a promising avenue for identification and development of antimicrobia agents as drug candidates for natural antibiotics.

\section{Significance of the Study}

-

Significant level of bioactive compounds (phytochemicals) in antibacterial of $A$. vera sap provide enhanced synergistic inhibitory activity against resistant enteric bacilli

- $\quad$ Phylo-diversity and genomic profiling offer a novel method for characterization of $A$. vera plant

- Application of phylogenetic analysis and genotyping aid characterization and development of natural antibiotics that are accessible and available with therapeutic benefit as drug candidates

\section{Introduction}

Over the years, inadvertent and uncontrolled use of antibiotics had resulted in the emergence of resistant bacteria strains to commonly used antibiotics; this necessitates developing newer antibiotics to check the prevailing infection [1], [2]. Highly diverse resistance to different antibiotic classes presents a very worrisome situation [3], [4]. This alarming trend necessitates an urgent search for an alternative source of antimicrobial agents, mostly from plant and herbal sources [5].

Various plants and herbs are now being harvested, processed and analyzed using biotechnology for human use, making the plants much more effective, 
fast, economical, and easily available. One such plant is Aloe vera. This plant belongs to the Lily Family having thick, green leaf-like structures that grow from a central point. It has been reported to have been used for the treatment of different aliments, mostly as a laxative and cosmetics [6]. Since centuries, the leaves and gel were been used as medicinal, beauty, and skincare [7]. It is now recognized in some developing countries that plants are the main therapeutic source to treat various infectious diseases, but its leaf latex extract has not been explored for its efficacy against prevailing communicable diseases and several enteric bacterial pathogens in Southwest Nigeria [8].

This latex was documented to contain phytochemical (bioactive) compounds such as anthraquinones and their derivatives such as BarbaloinIO-aloe, emodin-9-anthrone, Isobarbaloin, Anthrone-Cglycosides, and chromones which possess purgative, antimicrobial, analgesic, anti-inflammatory, and antibacterial properties [9]. Nevertheless, the phylogenetic analysis could suggest the probable antimicrobial active species of Aloe plants based on the geographical location and relatedness to other species [10].

Prevalent enteric infectious diseases (particularly diarrhea) characterized by severe loss of electrolytes through frequent stooling, abdominal pain and cramps, caused by pathogenic Gram-negative bacteria (such as Pseudomonas aeruginosa, Klebsiella pneumoniae, Escherichia coli, and Salmonella typhimurium) are becoming severe, with high intestinal morbidity mostly among children [11]. Therefore, this study focused on the anti-enteric bacteria activities and diversity of $A$. vera plant producing antibacterial latex in Nigeria.

\section{Methods}

\section{Biotype sampling}

Enteric bacilli of 251 were obtained from patients attending Federal Medical Centre which serve as one of the largest referral center for internal medicine in southwest Nigeria with ethical permission. Each isolate was characterized by cultural and cellular morphological examination and further biotyped using Analytic profile index kit (API 24E test KIT).

\section{Antibiotic assay}

Antibiogram of the biotypes was determined using Kirby-Bauer disc diffusion method [12] on Mueller Hinton for the panel of these antibiotics; Tetracycline $(30 \mu \mathrm{g})$, Cefuroxime $(30 \mu \mathrm{g})$, Clavulanic acid $(10 \mu \mathrm{g})$ + Amoxicillin $(20 \mu \mathrm{g})$, Ceftazidime $(30 \mu \mathrm{g})$, Gentamycin $(10 \mu \mathrm{g})$, Trimethoprim $(5 \mu \mathrm{g})$
+ Sulfamethaxazole $(25 \mu \mathrm{g})$, Ofloxacin $(10 \mu \mathrm{g})$, Ampicillin $(10 \mu \mathrm{g})$, and Ciprofloxacin $(10 \mu \mathrm{g})$. Inhibition zones produced were interpreted according to CLSI guidelines (2016) [13]. Minimum inhibitory concentration (MIC) of each antibiotic was evaluated with the use of standard broth micro-dilution assay [14], and isolates showing antibiotic MIC of $>16 \mu \mathrm{g} / \mathrm{mL}$ were selected as resistant.

\section{A. vera plant collection and examination}

More than $16 A$. vera plants commonly used for skin treatment and other nutraceuticals in southwest Nigeria were selected for this study and were examined for their morphological parameters [15], [16]. Based on the leaf length, which was measured from the base of attachment of the mature leaf to the tip of the leaf, the presence of white spots on leaves and arrangement and a number of spines present on each plant leaves were observed and recorded. The medial striation or lateral line was also examined in each plant leaves.

\section{Preparation of leaf latex}

The leaf latex was prepared as described with minor modifications [16]. Several healthy matured thick leaves of the Aloe plant were plucked from the stem and allowed to drain its fresh yellow latex for a period of 30 min into a sterile container. The latex was sterilized by steaming at $65^{\circ} \mathrm{C}$ for $15 \mathrm{~min}$ [17].

\section{Bioactive compound analysis}

Latex from 5 leaf strands of the same plant was pooled, and $1 \mathrm{ml}$ was diluted with $19 \mathrm{ml}$ of sterile water to make 1:20 dilution and estimated for alkaloids [18], tannins [19], anthraquinones, saponins [20], phenol [21], flavonoids, glycoside, phlobatannins [22], and terpenoids [23].

\section{activity}

\section{Spectrophotometric assay for antibacterial}

Adjusted 0.5 McFarland turbid broths of resistant biotypes were tested against varying dilutions of the latex in a standard micro-tube dilution bio-assay for determination of the minimum inhibitory dilution (MID) with sterile $1 \%$ peptone to serve as a control. The micro-plate was incubated at $37^{\circ} \mathrm{C}$ in ambient air for $24 \mathrm{~h}$. The absorbance of each well before and after incubation was measured using Jenway 6405UV/ Vis spectrophotometer microplate reader at $590 \mathrm{~nm}$ wavelength to determine the concentration of the bacterial growth (turbidity), which is proportional to the absorbance. Therefore, the MID is defined as the lowest concentration of the latex that shows no growth (showing similar absorbance as blank). The respective 
MIDs shown by the latex against the isolates were interpreted [24].

\section{Time kill kinetics}

This assay was carried out according to the modified method of Sopirala et al. [25] and Hedges [26]. Each overnight broth of 23 prepared $10^{5} \mathrm{CFU} / \mathrm{ml}$ antibiotic resistant biotypes was added to $1 \mathrm{ml}$ of different dilutions of latex and incubated on a shaker at $37^{\circ} \mathrm{C}$ in ambient air. Aliquots of $100 \mu \mathrm{l}$ were removed at $0,6,12,18$, and $24 \mathrm{~h}$ post-inoculation. At each 6 -h interval, the $100 \mu$ broth culture challenged with latex was serially diluted in sterile $0.85 \%$ standard saline solution to estimate the total viable colony count for a period of $24 \mathrm{~h}$ in $\log _{10} \mathrm{CFU} / \mathrm{ml}$.

\section{Polymerase chain reaction (PCR) amplification of internal transcribed spacer (ITS) gene marker}

Ribosomal DNA (rDNA) was extracted from $A$. vera leaf from using the Cetyl trimetyl ammonium bromide (CTAB) method as described by Doyle and Doyle [27] using newly emerging succulent healthy small young leaf shoot of the plant from which the latex was extracted for an antibacterial test. Harvested leaf shoot was brought in an ice pack to the Laboratory and thoroughly washed with tap water and rinsed with distilled water, blot dried, and weighed. Leaf tissue of $0.5 \mathrm{~g}$ was thoroughly homogenized in $2 \mathrm{ml} \mathrm{CTAB}$ buffer in a sterile mortar to form slurry, which was used to extract the DNA [28]. Precipitated rDNA was spooled and washed with $70 \%$ ethanol, dried at room temperature, and dissolved in $50 \mu$ of $1 \times$ TE buffer. The quality and quantity of extracted rDNA were estimated on Thermoscientific Nanodrop Spectrophotometer at the absorbance of $260 \mathrm{~nm}$ filter, and an appropriate quantity of PCR Mastermix was prepared. Amplification of conserved ITS region for genomic taxonomy of Asphodelaceae plants was performed using ITS4 and ITS5 primers (Table 1) [10].

Table 1: PCR Amplification protocol for ITS4 and ITS5 genes

\begin{tabular}{lllll}
\hline Primer & Primer Sequence $\left(5^{\prime}-3^{\prime}\right)$ & Target gene & $\begin{array}{l}\text { Amplicon } \\
\text { size }(\mathrm{bp})\end{array}$ & Reference \\
\hline ITS 4 & TCC TCC GCT TAT TGA TAT GC & ITS 4 & 165 & {$[10]$}
\end{tabular}

ITS5 GGAAGTAAAAT CGTAAC AAG G ITS $5 \quad 614$

PCR assay was carried out in a volume of $20 \mu \mathrm{l} 2 \times$ PCR buffer, $1.5 \mu \mathrm{l} 25 \mathrm{mM} \mathrm{MgCl}, 0.5 \mu \mathrm{l}$ of $10 \mathrm{mM}$ dNTPs (dATP, dGTP, dCTP, and dTTP), $0.2 \mu \mathrm{l}$ ITS 4 primer of 2500 pmole, $0.2 \mu$ l of ITS 5 primer of 2500 pmole, $0.2 \mu \mathrm{l}$ Taq polymerase enzymes, $15.4 \mu \mathrm{l}$ distilled water, and $2.0 \mu \mathrm{l}$ of each extracted chromosomal DNA template to make final reaction volume of $20.0 \mu \mathrm{l}$. The amplification reaction was carried out in 26 cycles of denaturation at $97^{\circ} \mathrm{C}$ for $60 \mathrm{~s}$, annealing at $50^{\circ} \mathrm{C}$ for 60 $\mathrm{s}$, and elongation at $72^{\circ} \mathrm{C}$ for $3 \mathrm{~min}$.

\section{ITS amplicon sequencing}

Amplicon products were cleaned and purified using QIAquick PCR purification kit (Qiagen, USA) and quantified with Thermoscientific Nanodrop Spectrophotometer at an absorbance of $260 \mathrm{~nm}$ to obtain the required dilution of amplicon for sequencing. Six microliters of diluted DNA was added to $4 \mu$ of ITS primer at a concentration of $0.8 \mathrm{pmol} / \mu \mathrm{l}$ to make final reaction mixtures $10 \mu \mathrm{l}$, which was added to Taqcycle sequencing kit (containing tag-oligonucleotide Taq polymerase) according to manufacturer's instruction (Applied Biosystem Company, USA) and sequenced using ABI Prism Big Dye Terminator version 3.0 cycle and sequenced products subsequently analyzed on an ABI PRISM 3700 DNA Analyzer. Homological analyses were performed by aligning the raw nucleotide sequence product into BLAST (Basic Local Alignment Search Tool) Web-based tool of the National Institutes of Health (NIH, USA) software to search similar submitted nucleotide sequences and homologous sequences of more than $98 \%$ were selected with their respective accession number, nucleotides sequences, and location.

\section{Phylogenetic analysis}

Diversity of the $A$. vera sequences was analyzed using MEGA software version 6 [29], where nucleotide sequences were manually aligned to make a phylogenetic tree with maximum parsimony assessing the sequences as independent, unordered, and equally weighted, according to Fitch parsimony [29]. Fitch bootstrap percentages were calculated for each node (bootstrap option in PAUP 3.1.1., with 1000 replicates of heuristic search).

\section{Data analysis}

The significance of the resistant bacteria susceptibility was determined using Chi-square and bioactive compound from latex by t-test $(p<0.05)$. Analysis of variance (ANOVA) for the significance of the antimicrobial activity of each of the species of the Aloe barbadensis miller against different multi-antibiotic resistant enteric biotypes and level of the bioactive compound was correlated with antibacterial activity $(p<0.05)$.

\section{Results}

\section{Resistance profile of enteric biotypes}

Among the 251 collected enteric biotypes, Citrobacter freundii (14.3\%), E. coli (13.4\%) and Proteus mirabilis (9.1\%) showed resistance to more 


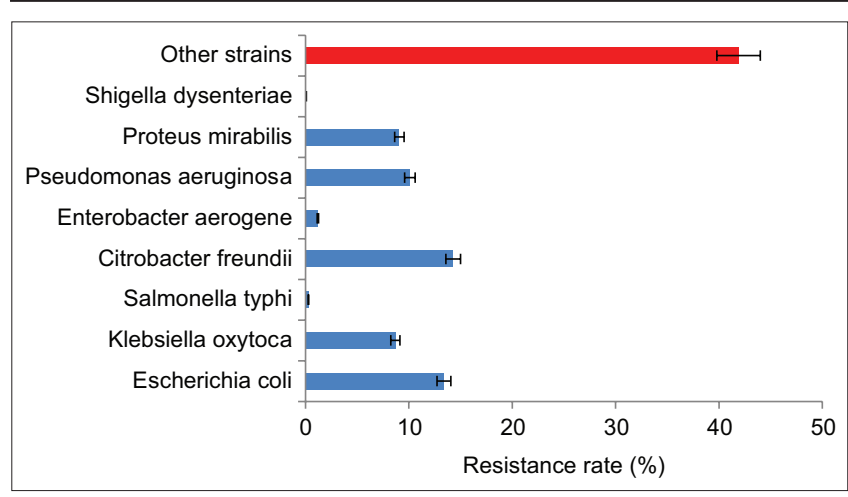

Figure 1: Antibiotic resistant rates of collected enteric biotypes from fecal samples (Other strains indicate collections of several identified bacteria isolates)

than two classes of antibiotics by disc diffusion assay (Figure 1). Only $44.7 \%, 38.9 \%$, and $33.9 \%$ were significantly resistant to cotrimoxazole, ciprofloxacin, and tetracycline, respectively, with MIC $>16 \mu \mathrm{g} / \mathrm{ml}$ $(p=0.004)$ (Figure 2).

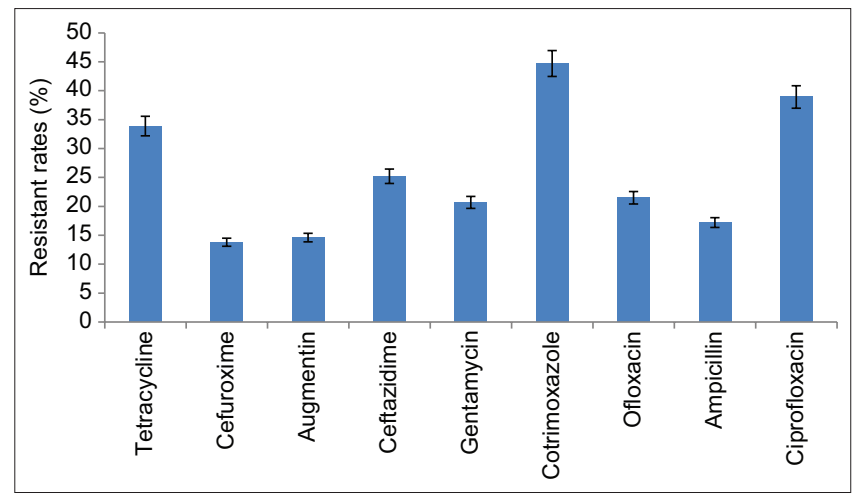

Figure 2: Resistance pattern of the recovered enteric bacilli strains $(n=251)$ to various antibiotics at minimum inhibitory concentration $>16 \mu \mathrm{g} / \mathrm{ml}$

\section{Antimicrobial activity and time-kill kinetics of latex against multi-antibiotic resistant biotypes}

From the $A$. vera plant latex of 16 variants tested against the resistant isolates, only variants $A$, $\mathrm{B}$, and $\mathrm{C}$ showed significant $\mathrm{MID}_{50}$ and $\mathrm{MID}_{90}$ (Table 2). Among the $A$. vera with significant MID, the overall activity $A$. vera latex from designated variant $A$ showed a significant inhibitory rate (39.5\%) against resistant enteric biotypes at MID 1:16 compared to $5.3 \%$ and $2.6 \%$ recorded from other two variants (Figure 3 ). More than $50 \%$ inhibitory rate was recorded against Klebsiella oxytoca, Salmonella species, Enterobacter cloaca, and $P$. mirabilis. Latex from variant $A$ showed a significant average reduction rate in viable colony count for all the enteric bacterial isolates at $1 \times \mathrm{MIC}$ and $2 \times \mathrm{MIC}$ to $<3.0 \log _{10} \mathrm{CFU} / \mathrm{mL}$ after $24 \mathrm{~h}$, which is an indication of bacteriocidal activity except resistant $P$. aeruginosa, which recorded more than $3.0 \log _{10} \mathrm{CFU} / \mathrm{mL}$ at $1 / 2$ $\times$ MIC after $24 \mathrm{~h}$ incubation (Table 3 ). The levels of flavonoids, alkaloids, terpenoids, and anthraquinone in $A$. vera variant $A$ significantly correlated and regressed
Table 2: Minimum inhibitory dilution (MID) of variants Aloe vera latex against multi-antibiotic resistant isolates

\begin{tabular}{llll}
\hline Aloe vera variants & $\mathrm{MID}_{50}$ & $\mathrm{MID}_{90}$ & p value \\
\hline $\mathrm{A}$ & 1 & 8 & 0.001 \\
$\mathrm{~B}$ & 2 & 8 & 0.001 \\
$\mathrm{C}$ & 2 & 16 & 0.001 \\
$\mathrm{D}$ & 8 & 16 & 0.053 \\
$\mathrm{E}$ & 8 & 32 & 0.064 \\
$\mathrm{~F}$ & 8 & 32 & 0.055 \\
$\mathrm{G}$ & 8 & 32 & 0.051 \\
$\mathrm{H}$ & 8 & 64 & 0.059 \\
$\mathrm{I}$ & 16 & 64 & 0.061 \\
$\mathrm{~J}$ & 16 & 64 & 0.054 \\
$\mathrm{~K}$ & 32 & 128 & 0.050 \\
$\mathrm{~L}$ & 32 & 128 & 0.058 \\
$\mathrm{M}$ & 64 & 256 & 0.082 \\
$\mathrm{~N}$ & 64 & 512 & 0.075 \\
$\mathrm{O}$ & 64 & 512 & 0.071 \\
$\mathrm{P}$ & 128 & 512 & 0.052 \\
\hline $\mathrm{p}<0.05$ significant. & & &
\end{tabular}

with antibacterial activity $(p<0.05)$, as shown in Table 4.

\section{Phylogenetic diversity}

Only 16 A. barbadensis miller plants with more than $98 \%$ homologous sequences were selected from GenBank and were analyzed for phylogenetic diversity with nucleotide sequences of $A$. barbadensis miller from Nigeria using Maximum parsimony at $<50 \%$ bootstrapping reliability (Figure 4 ).
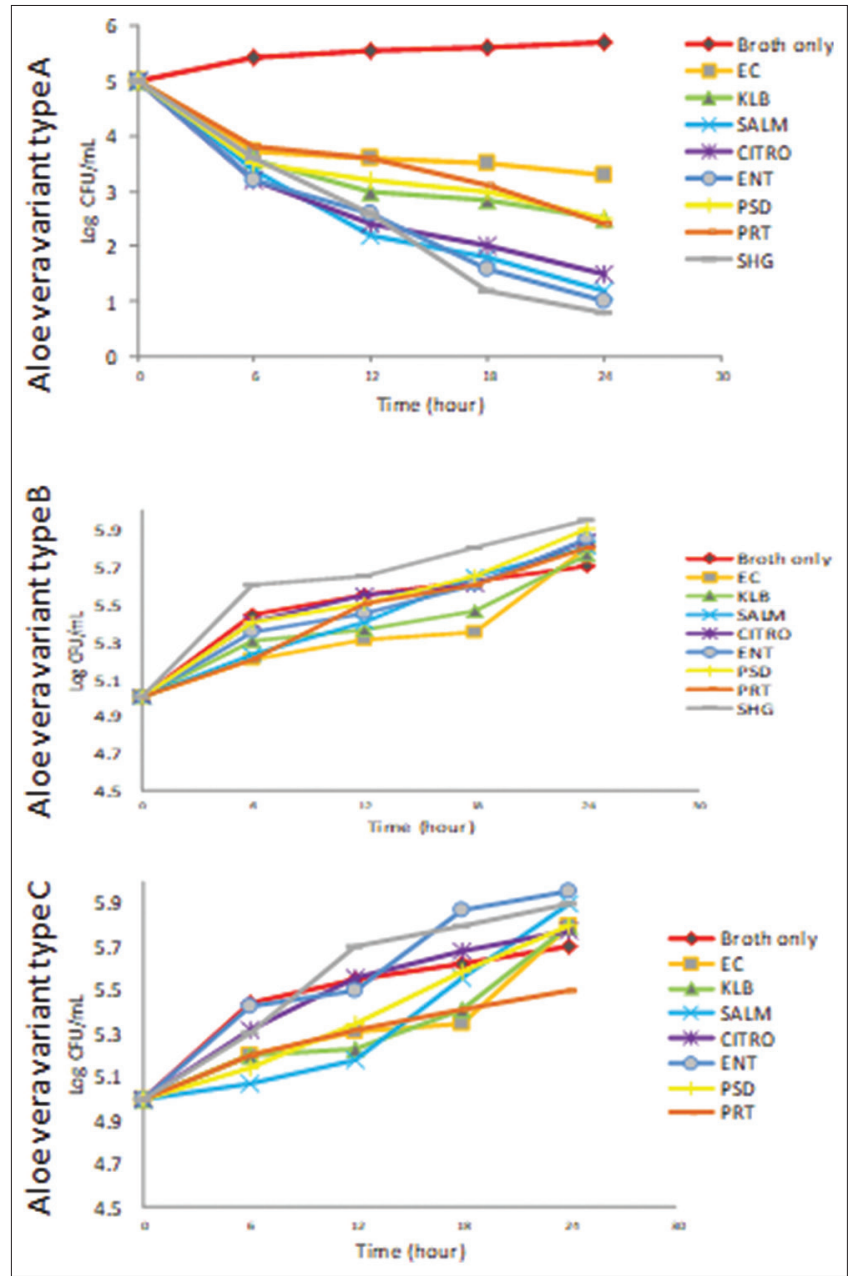

Figure 3: Kinetic of latex inhibitory activity at optimum minimum inhibitory dilution (1:16) of Aloe barbadensis miller variants against resistant enteric strains 
Table 3: Evaluation of Time kill rate of Aloe barbadensis miller latex from variant $A$

\begin{tabular}{|c|c|c|c|c|c|c|c|c|c|}
\hline \multirow[t]{3}{*}{ Enteric isolates } & \multicolumn{9}{|c|}{$\log _{10} \mathrm{CFU} / \mathrm{mL}$} \\
\hline & \multicolumn{3}{|c|}{$2 \times \mathrm{MIC}$} & \multicolumn{3}{|c|}{$1 \times \mathrm{MIC}$} & \multicolumn{3}{|c|}{$1 / 2 \times \mathrm{MIC}$} \\
\hline & $\overline{\mathrm{Oh}}$ & $12 \mathrm{~h}$ & $24 \mathrm{~h}$ & $\overline{\mathrm{Oh}}$ & $12 \mathrm{~h}$ & $24 \mathrm{~h}$ & $\overline{\mathrm{Oh}}$ & $12 \mathrm{~h}$ & $24 \mathrm{~h}$ \\
\hline Escherichia coli & 5.01 & 3.32 & 2.50 & 5.02 & 3.38 & 2.79 & 5.70 & 3.52 & 3.12 \\
\hline Salmo & 5.03 & 3.12 & 2.56 & 5.05 & 3.27 & 2.78 & 5.02 & 3.44 & 2.94 \\
\hline Citrobacter freundii & 5.00 & 3.01 & 2.50 & 5.23 & 3.21 & 2.95 & 5.32 & 3.50 & 3.21 \\
\hline Pseudomonas aeruginosa & 4.98 & 2.85 & 2.51 & 5.12 & 3.20 & 3.00 & 5.21 & 3.50 & 3.23 \\
\hline Proteus mirabilis & 4.87 & 3.01 & 2.74 & 5.10 & 3.28 & 2.90 & 5.10 & 3.40 & 3.03 \\
\hline Shigella species & 5.32 & 2.85 & 2.24 & 5.06 & 3.22 & 2.54 & 5.15 & 3.46 & 3.00 \\
\hline
\end{tabular}

A. barbadensis miller variant $A$ (Nigeria) clustered with $A$. vera species HE995579 Canaria, Spain; $A$. vera GQ435495 Haidian, China; and $A$. vera variant $\mathrm{B}$ (Nigeria) to clade C. Only two A. vera AJ512309 Heidelberg, Germany; A. vera AJ290298 Surrey, UK; A. vera AY323649 Heidelberg, Germany; A. vera AY323649.1 Heidelberg, Germany; A. vera JQ273907 Missouri, USA and $A$. vera JQ273907.1 Missouri, USA clustered into clade $A$. Clade $D$ is distinct, clustering only the Nigerian $A$. vera variant $C$ with $A$. vera L05029 Missouri, USA.

\section{Discussion}

High rate of enteric biotypes including C. freundii, E. coli, and $P$. mirabilis showing resistance to Cotrimoxazole, Ciprofloxacin, and Tetracycline, respectively, at $\mathrm{MIC}>16 \mu \mathrm{g} / \mathrm{ml}$ suggest consistent resistance to most commonly used antibiotics in Nigeria, and this would continue to be a growing problem with increase morbidity especially in children [30]. The increasing antimicrobial resistance observed in this study is primarily linked to excessive and unnecessary antibiotics use in humans and food animals coupled with low health orientation and guidelines [31], [32]. Surveillance of multi-resistant enteric isolates in healthy populations has demonstrated commensals also constituting a rich reservoir of genetic material from which pathogens can readily transfer resistance on mobile genetic elements [33].

Table 4: Analysis of latex susceptibility with its phytochemical compounds

\begin{tabular}{|c|c|c|c|c|c|c|}
\hline \multirow[t]{2}{*}{ Physicochemical properties } & \multicolumn{2}{|c|}{ Correlation analysis } & \multicolumn{4}{|c|}{ Regression analysis } \\
\hline & $r$-value & $p$-value & Coefficient ( $\beta$ ) & SE & $\mathrm{t}$-value & p-value \\
\hline Tannins & 0.326 & 0.405 & -109.647 & 111.219 & -1.524 & 0.378 \\
\hline Phenol & 0.040 & 0.691 & 10.201 & 29.427 & 0.340 & 0.846 \\
\hline Flavonoids & 0.714 & 0.017 & 21.245 & 19.136 & 2.145 & $0.028^{*}$ \\
\hline Glycosides & 0.217 & 0.755 & -135.090 & 42.605 & -0.584 & 0.871 \\
\hline Steroids & 0.139 & 0.636 & 194.930 & 105.567 & 1.053 & 0.323 \\
\hline Phlobatannins & 0.041 & 0.889 & 192.545 & 256.97 & 0.479 & 0.599 \\
\hline Alkaloids & 0.621 & $0.023^{*}$ & 65.321 & 61.23 & 1.872 & $0.020^{*}$ \\
\hline Anthraquinone & 0.607 & $0.034^{*}$ & 11.763 & 53.983 & 3.740 & $0.039^{*}$ \\
\hline Terpenoids & 0.502 & $0.043^{*}$ & 30.265 & 18.402 & 3.976 & $0.046^{*}$ \\
\hline
\end{tabular}

${ }^{*} p<0.05$ is significant

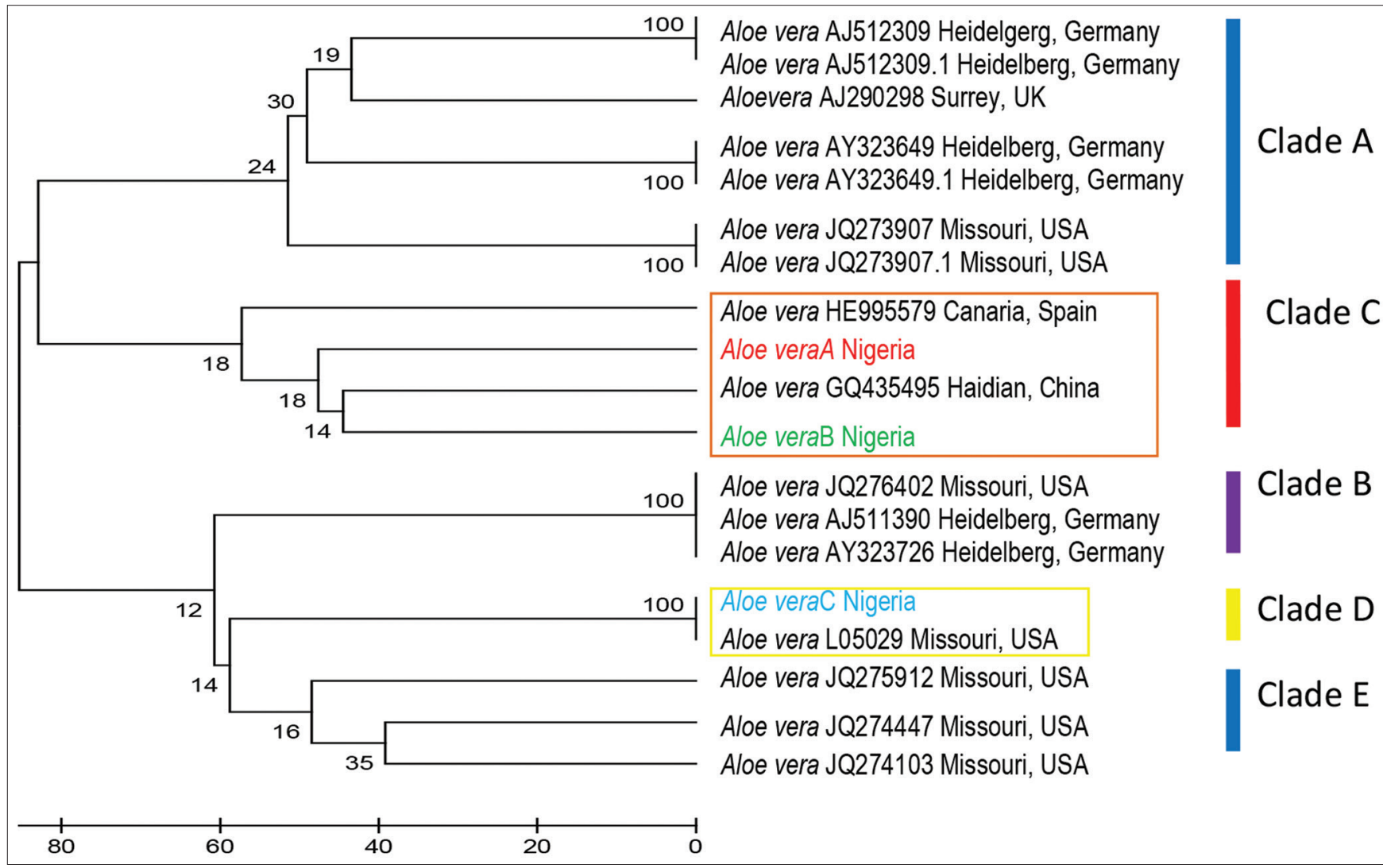

Figure 4: Phylogenetic diversity of Nigerian Aloe vera variants with repository A. vera metadata deposited in GenBank (colored black with GenBank accession number, location and country, bootstrapping values at node indicating level of tree reliability and scale bar indicating nucleotide sequence homology) 
Despite the continued emergence of resistant enteric bacteria strains, $A$. vera has been identified as an alternative remedy from natural products that can circumvent resistance mechanisms, improve the containment, treatment, and eradication of these strains [9]. Preliminary examination of various Aloe plants indicated only three variants from this location to have antibacterial activities. The morphological and floral features reveal distinct structures in spine arrangement, white spot distribution, and greenish coloration that are not descriptive enough for the taxonomy of the medicinal Aloe species [34].

However, there are discrepancies between classical taxonomy [35] within the Asphodelaceae, the sub-family Alooideae, which is now recognized as difficult to classify of its succulent leaf morphology [36]. The uncertainty eroded biosynthetic investigations of the leaf latex phytochemical studies to presumably differentiate various species [34], [37]. Phytochemicals, defined as non-nutrient chemical compounds or bioactive components responsible for protecting the plant against microbial infections or infestations by pests [38], [39], are of significant proportion in latex from Nigerian $A$. vera.

There is a paucity of reports of anti-enteric bacilli activities of latex solution of Nigerian Aloe plants with variation in flavonoids, alkaloids, terpenoids, anthraquinone, and glycosides level. This study observed the effect of environmental changes and geographical location as attributable factors for its antimicrobial efficacy. However, these latexes' activity on resistant biotypes is a promising development of antibacterial agents with potent inhibitory action [40]. Antibacterial activity of tested latex showing significant inhibitory action at low dilutions (MID) suggests effect of high flavonoids, alkaloids, and tannin as antioxidants that makes effective scavenging for reactive oxygen species (including superoxide anions and hydroxyl radicals) as well as other free radicals causing damage to bacteria cellular functions. These activities result in oxidative stress leading to cytotoxic damage by removing "free-oxygen radicals," thereby giving rise to metastable radicals, which tend to trap electrons from the molecules in immediate surroundings [41], [42].

Evaluation of time-kill kinetics over $24 \mathrm{~h}$ caused a high reduction rate in viable colony count for all the bacterial strains at $2 \times \mathrm{MIC}$, which is defined as bacteriocidal [43]. Nonetheless, $<2.42 \log _{10} \mathrm{CFU} / \mathrm{mL}$ count recorded at 1:16 dilution further confirmed this natural product's potency with dependable efficacy as a growth inhibitory agent with dose and time-dependent to produce an effective time-kill rate. The effectiveness of time-kill kinetics may be accounted for by the synergistic activity of individual phytochemical compounds that possibly enhance the antibacterial action in sequential antioxidation of saponin, flavonoids, anthraquinine, and alkaloids. Of which saponin disrupts the outer phospholipidic membrane carrying the structural lipopolysaccharide components of the cell wall of bacteria cell leading to its permeability for other phytochemical compounds into bacteria cytosol [44], [45] and alkaloids causing inhibition of outer membrane bacteria cell wall synthesis, thereby damaging the cell membrane barrier function allowing other compound(s) to diffuse into the bacterial cells [46], [47].

Similarly, alkaloids act as DNA intercalating agents that adversely affect DNA replication [48], while flavonoids and phenol deprive hydrogen bonding, protein, and some microbial enzymes metabolism resulting in inhibition of bacteria cell replication and cytosol metabolic activities [49]. Culminated synergistic antibacterial activities of these phytochemical compounds through different mechanisms would not be circumvented by resistant bacteria. This was further confirmed by correlation and regression analysis, providing evidence of some bioactive compounds effectively producing antibacterial activity.

In spite of this antibacterial activity, hundreds of $A$. vera plant species had been identified in different parts of the World, but only a few had been characterized to be of medicinal importance. The Nigerian $A$. vera variants clustered with $A$. vera from Spain and China confirm the plants distinct phylogenetic diversity. Similar diversity was observed in Nigerian Aloe plant (A. vera A type) with other species from Germany, UK, and USA that clustered into clade $A$ while clade $D$ is distinctly clustering with other Nigerian variant species of $A$. vera from Missouri, USA. To a greater extent, the diversity of these plants reveals genomic unrelatedness with high polymorphism despite the geographical origin [50]. This could infer other $A$. vera in these clades possess high-level antimicrobial properties as they shared related genetic makeup [51]. Thus, showing the usefulness of genetic diversity as a reliable tool for improved taxonomy of $A$. vera of medicinal importance. Genetic diversity clearly predicts classification and identification of antimicrobial $A$. vera species sharing a typical genomic nucleotide profile [52], phylogenetic variation, and signature on nuclear DNA regions as reliable markers for characterization of homogeneity and detection of adulterant variants [50]. This would assure quality control in medicinal plant research and the production, clinical use, and forensic examination of A. vera to develop antimicrobial agents [51].

However, an important qualitative aspect of genomic architecture is nucleotide compositions, which express GC content. This would be needed to further identify various Aloe species and differentiate by the genomic impact of DNA composition phenotypically expressed in the absence of spot patches and lateral, medial line in some plants [53], [54]. In the recent past, considerable attention has been given to the biological relevance of GC ratio [55], having known only for the amount of the total phylogenetic diversity [56], [57] and high thermal stability that confers stability to many Aloe plants adaptability [58]. 


\section{Conclusion}

The efficacy of $A$. vera latex as an antibacterial agent on resistant enteric bacilli could provide alternative therapy, and the synergistic activity of various phytochemical compounds would make this latex a novel, natural and antibacterial product. Phylodiversity analysis would further offer a promising avenue for medicinal variant identification and development of antimicrobial agents accessible, available, and therapeutic benefit as drug candidates in research for natural antibiotics.

\section{Acknowledgments}

The authors kindly appreciate the staff of Pathology Department of Federal Medical Centre, Abeokuta for their helping in the collection and storage of the bacterial isolates and staff of Pure and Applied Botany, Federal University of Agriculture, Abeokuta, Nigeria for characterization of the selected Aloe plants.

\section{Data Availability}

The data supporting the results of this study are available on request to the corresponding author.

\section{Authors' Contributions}

Akinduti Paul A - conceptualization; methodology; data collection; sample analysis; data analysis; validation; data curation; writing - the initial draft; writing - revisions; student supervision; project leadership; project management; and funding acquisition.

Isibor Patrick O - data collection; sample analysis; data analysis; validation; data curation; writing - the initial draft; writing - revisions; and funding acquisition.

Obafemi Yemisi D - conceptualization; methodology; data collection; sample analysis; student supervision; project leadership; project management; and funding acquisition.

Ishola R - methodology; data collection; validation; data curation; project management.

Ahuekwe E.F - data analysis; validation; data curation; writing - revisions; student supervision; project leadership; project management; and funding acquisition.

Ayodele Olufunmilayo A - conceptualization; methodology; data collection; sample analysis; data analysis; validation; writing - revisions; project management.

Oduleye O.S - data collection; sample analysis; data analysis; validation; data curation; writing revisions; student supervision; and funding acquisition.

Oziegbe O - sample analysis; data analysis; validation; data curation; writing - revisions; student supervision; project leadership; and funding acquisition.

Onagbesan K.O - conceptualization; methodology; data collection; sample analysis; data analysis; validation; data curation; writing - the initial draft; writing - revisions; student supervision; project leadership; project management.

\section{References}

1. Goud S, Raghavendra S, Shylaja M, Babu J. The detection and antimicrobial susceptibility profile of Shigella isolates in and around Hyderabad, Telangana. J Pharm Innov. 2018;7:84-8.

2. Akinduti PA, Olasehinde GI, Ejilude O, Taiwo OS, Obafemi YD. Fecal carriage and phylodiversity of community-acquired blaTEM Enteric bacilli in Southwest Nigeria. Infect. Drug Resist. 2018;11(24):25-33. http://doi.org/10.2147/IDR.S178243 PMid:30568469

3. Iliyasu MY, Uba A, Agbo EB. Phenotypic detection of multidrug resistant extended-spectrum beta-lactamase (ESBL) producing Escherichia coli from clinical samples. Afr J Cell Pathol. 2018;10(2):25-32. http://doi.org/10.5897/AJCPath2018.0004

4. Ugwu MC, Shariff M, Nnajide CM, Beri K, Okezie UM, Iroha IR, et al. Phenotypic and molecular characterization of $\beta$-lactamases among enterobacterial uropathogens in Southeastern Nigeria. Can J Infect Dis Med Microbiol. 2020;2020:5843904. http://doi. org/10.1155/2020/5843904

PMid:32184910

5. Romulo A, Zuhud EA, Rondevaldova J, Kokoska L. Screening of in vitro antimicrobial activity of plants used in traditional Indonesian medicine. Pharm Biol. 2018;56(1):287-93. http://doi. org/10.1080/13880209.2018.1462834

PMid:29656672

6. Andrea B, Dumitrița R, Florina C, Francisc D, Anastasia V, Socaci $\mathrm{S}$, et al. Comparative analysis of some bioactive compounds in leaves of different Aloe species. BMC Chem. 2020;14(1):67. http://doi.org/10.1186/s13065-020-00720-3 PMid:33292458

7. Musara C, Aladejana EB. Review of studies on Bulbine natalensis Baker (Asphodelaceae): Ethnobotanical uses, biological and chemical properties. J Appl Pharm Sci. 2020;10(9):150-5. http:// doi.org/10.7324/JAPS.2020.10918

8. Akinduti PA, Oluwadun A, Olugbuyiro JA, Osuagwu CS, Ejilude $\mathrm{O}$, Onagbesan $\mathrm{KO}$, et al. Antimicrobial activity and time kill kinetics of Nigerian Honeys on multi-resistant Enteric Bacilli. IOP Conf Ser Environ Earth Sci. 2018;210(1):012003.

9. Danish P, Ali Q, Hafeez MM, Malik A. Antifungal and antibacterial activity of Aloe vera plant extract. Biol Clin Sci Res 
J. 2020;3:1-14.

10. Peska V, Garcia S. Origin, diversity, and evolution of telomere sequences in plants. Front Plant Sci 2020;11:117-26.

11. Abid S, Kaliraj L, Arif MH, Hurh J, Ahn JC, Yang DC, et al. Molecular and morphological discrimination of Chrysanthemum indicum using allele-specific PCR and T-shaped trichome. Mol Biol Rep. 2020;47(10):7699-708.

PMid:32974840

12. Khan ZA, Siddiqui MF, Park S. Current and emerging methods of antibiotic susceptibility testing. Diagnostics. 2019;9(2):49-66. http://doi.org/10.3390/diagnostics9020049 PMid:31058811

13. Clinical and Laboratory Standard Institute. Twenty-first Informational Supplement, CLSI Document M100-S21, Performance Standards for Antimicrobial Susceptibility Testing. Wayne, PA: Clinical and Laboratory Standards Institute; 2018.

14. Nadir S, Adienge A, Muturi GM, Kinyua J, Ngaira J, Gicheru JM. Genetic diversity and population structure of three commercial indigenous Aloe species in selected ASALs of Kenya. J Plant Mol Breed. 2019;8(1):1-10. http://dx.doi.org/10.7243/2050-2389-8-1

15. Bala AG, Hassan MR, Tanko RJ, Amodu JT, Bature MS, Hassan $\mathrm{AH}$, et al. Forage potentials of two cowpea (Vigna unguiculata $\mathrm{L}$. Walp) varieties as influenced by varying irrigation frequencies and phosphorus application rates in Zaria. Niger $\mathrm{J}$ Anim Prod. 2020;47(1):269-77.

16. Thielmann J, Muranyi P, Kazman P. Screening essential oils for their antimicrobial activities against the foodborne pathogenic bacteria Escherichia coli and Staphylococcus aureus. Heliyon. 2019;5(6):e01860. https://doi.org/10.1016/j.heliyon.2019. e01860

17. Ajayi OF, Olasunkanmi OO, Agunbiade MO, Alayande KA, Aiyegoro, OA, Akinpelu DA. Study on antimicrobial and antioxidant potentials of Alchornea cordifolia (Linn.): An in vitro assessment. Trans R Soc S Afr. 2020;75(3):266-81. https://doi. org/10.1080/0035919X.2020.1830868

18. Oladele AC, Olumayowa AA, Temitope OS. Phytochemical and antimicrobial activity of ethnomedicinal leaf extract of selected plants in Nigeria. World J Adv Res Rev. 2020;7(1):253-62. http:// doi.org/10.30574/wjarr.2020.7.1.0256

19. Kutama RM, Adbulkadi RS, Kwalli SA, Chiroma G. Phytochemical compositions in some Nigerian medicinal plants and their pharmacological properties: A review. Int J Anesth Clin Med. 2018;6(1):15-25.

20. Achikanu CE, Ani ON. Nutritional and phytochemical content of Cissus populnea (Okoho) stem bark. Asian J Res Biochem. 2020;7(3):8-15. http://doi.org/10.9734/ajrb/2020/v7i330139

21. Dey P. The pharmaco-toxicological conundrum of oleander: Potential role of gut microbiome. Biomed Pharmacother. 2020;129(1):110422. http://doi.org/10.1016/j. biopha.2020.110422 PMid:32563990

22. Hapsari BW, Manikharda M, Setyaningsih W. Methodologies in the analysis of phenolic compounds in Roselle (Hibiscus sabdariffa L.): Composition, biological activity, and beneficial effects on human health. Horticulturae. 2021;7(2):35-76. https:/ doi.org/10.3390/horticulturae7020035

23. Arulmozhi P, Vijayakumar S, Kumar T. Phytochemical analysis and antimicrobial activity of some medicinal plants against selected pathogenic microorganisms. Microb Pathog. 2018;123:219-26. http://doi.org/10.1016/j.micpath.2018.07.009 PMid:30009969

24. Tesk A, Freitas F, Kemper RT, Vieira TB. Evaluation of antibacterial activity from different Aloe vera (L.) Burm. F. extracts against Staphylococcus aureus strains. Sci Electron Arch. 2020;13(9):74-9. http://doi.org/10.36560/13920201190

25. Shinohara DR, Menegucci TC, Fedrigo NH, Migliorini LB,
Carrara-Marroni FE, Dos Anjos MM, et al. Synergistic activity of polymyxin $B$ combined with vancomycin against carbapenemresistant and polymyxin-resistant Acinetobacter baumannii: First in vitro study. J Med Microbiol. 2019;68(3):309-15. PMid:30663954

26. Flamm RK, Rhomberg PR, Lindley JM, Sweeney K, EllisGrosse EJ, Shortridge, D. Evaluation of the bactericidal activity of fosfomycin in combination with selected antimicrobial comparison agents tested against gram-negative bacterial strains by using time-kill curves. Antimicrob Agents Chemother. 2019;63(5):e02549-18. http://doi.org/10.1128/AAC.02549-18 PMid:30858207

27. Doyle JJ, Doyle JL. A rapid DNA isolation procedure for small quatities of fresh leaf tissue. Phytochem Bull. 1987;19:11-5.

28. Tiwari S, Tomar RS, Tripathi MK, Ahuja A. Modified protocol for plant genomic DNA isolation. Indian Res J Genet Biotech. 2017;9(4):478-85.

29. Khan NT. MEGA-core of phylogenetic analysis in molecular evolutionary genetics. J Evol Biol. 2017;5(2):1000183.

30. Abdelwahab R, Yasir M, Godfrey RE, Christie GS, Element SJ, Saville $\mathrm{F}$, et al. Antimicrobial resistance and gene regulation in Enteroaggregative Escherichia coli from Egyptian children with diarrhoea: Similarities and differences. Virulence. 2021;12(1):5774. http://doi.org/10.1080/21505594.2020.1859852 PMid:33372849

31. Akinduti PA, Oluwadun A, Osiyemi J, Ejilude O, Isibor, PO. Multiantibiotics resistant relatedness of bla-gene encoded enteric bacteria harbouring high molecular R-plasmids. IOP Conf Ser Environ Earth Sci. 2018;210(1):012002.

32. Jibril AH, Okeke IN, Dalsgaard A, Menéndez VG, Olsen JE. Genomic analysis of antimicrobial resistance and resistance plasmids in Salmonella serovars from poultry in Nigeria. Antibiotics. 2021;10(2):99. http://doi.org/10.3390/ antibiotics10020099

PMid:33498344

33. Akinduti PA, Aboderin BW, Oloyede RI, Joseph I, Ogiogwa, Motayo BO, Ejilude O. High-level multi-resistant and virulent Escherichia coli in Abeokuta, Nigeria. J Immunoassay Immunochem. 2016;37(2):119-29. http://doi.org/10.1080/15321 819.2015.1063504

PMid:26263915

34. Kolano B, McCann J, Oskędra M, Chrapek M, Rojek M, Nobis A, et al. Parental origin and genome evolution of several Eurasian hexaploid species of Chenopodium (Chenopodiaceae). Phytotaxa. 2019;392(3):163-85.

35. Awotedu OL, Ogunbamowo PO, Chukwudebe EP, Ariwoola OS Medicinal based plants: A call to nature. World News Nat Sci. 2020;31:92-109.

36. Boucher FC, Quatela AS, Ellis AG, Verboom GA. Diversification rate vs. diversification density: Decoupled consequences of plant height for diversification of Alooideae in time and space. PLoS One. 2020;15(5):e0233597. http://doi.org/10.1371/ journal.pone.0233597 PMid:32453786

37. Bajpai S. Biological importance of Aloe vera and its active constituents. In: Synthesis of Medicinal Agents from Plants. Amsterdam, Netherlands: Elsevier; 2018. p. 177-203.

38. Akinduti PA, Ejilude $O$, Olugbuyiro J, Adewale AG, Onagbesan $\mathrm{O}$, Afolabi $\mathrm{O}$. Geospatial investigation of nigerian honey and detection of anti-enteric biomarker. Evid Based Complement Alternat Med. 2020;2020:9817673. http://doi. org/10.1155/2020/9817673 PMid:32419836

39. Birhan M, Tessema T, Kenubih A, Yayeh M. In vitro antimicrobial evaluation of aqueus methanol extracts from Calpurina aurea 
(Fabaceae) leaves. Asian J Pharm Res. 2018;8(4):33-43.

40. Gorsi FI, Kausar T, Murtaza MA. Evaluation of antibacterial and antioxidant activity of Aloe vera (Aloe barbadensis Miller) gel powder using different solvents. Pure Appl Biol. 2019;8(2):126570. http://dx.doi.org/10.19045/bspab.2019.80068

41. Li Y, Jiang JG. Health functions and structure-activity relationships of natural anthraquinones from plants. Food Funct. 2018;9(12):6063-80. http://doi.org/10.1039/c8fo01569d PMid:30484455

42. Sadeek AM, Abdallah EM. Phytochemical compounds as antibacterial agents a mini review. Saudi Pharm J. 2019;7(4):1-6.

43. Zhang $\mathrm{Y}$, Zhao $\mathrm{C}$, Wang $\mathrm{Q}$, Wang $\mathrm{X}$, Chen $\mathrm{H}$, Li H, et al. Evaluation of the in vitro activity of new polymyxin $B$ analogue SPR206 against clinical MDR, colistin-resistant and tigecyclineresistant Gram-negative bacilli. J Antimicrob Chemother. 2020;75(9):2609-15. http://doi.org/10.1093/jac/dkaa217 PMid:32591806

44. Akuru UB, Amadi BA. Phytochemicals and antioxidant properties of some selected medicinal plants. J Pharmacogn Phytochem. 2018;7(5):283-5.

45. likasha AM, Bock R, Mumbengegw DR. Phytochemical screening and antibacterial activity of selected medicinal plants against laboratory diarrheal bacteria strains. J Pharmacogn Phytochem. 2017;6(5):233-4.

46. Vetal DS, Pardeshi AB. Larvicidal potential of Argemone mexicana L. Plant extracts against Spodoptera litura fab. J Pharm Innov. 2019;8(6):698-702.

47. Abarca LF, Klinkhamer PG, Choi YH. Plant latex, from ecological interests to bioactive chemical resources. Planta Med. 2019;85(11/12):856-68. http://doi.org/10.1055/a-0923-8215 PMid:31137048

48. Sokefun $\mathrm{OO}$, Eleyowo, OO, Avungbeto, MO. In vitro antioxidant and antibacterial activity of Bridelia atroviridis (Arasado). J Altern Complement Med Res. 2017;2(4):4040254. http://doi. org/10.1155/2017/4040254 PMid:28491106

49. Akkachairin B, Rodphon $W$, Reamtong $O$, Mungthin $M$, Tummatorn J, Thongsornkleeb C, et al. Synthesis of neocryptolepines and carbocycle-fused quinolines and evaluation of their anticancer and antiplasmodial activities. Bioorg Chem. 2020;98(1):103732. http://doi.org/10.1016/j. bioorg.2020.103732

PMid:32171989

50. Abirami S, Jabesta J, Renitta RE, Anand DA, Samrot AV Antimicrobial activity of flower extracts against wound pathogens and fungi. Curr Res Green Sustain Chem. 2021;4:100076. https://doi.org/10.1016/j.crgsc.2021.100076

51. Jaiswal S, Antala TJ, Mandavia MK, Chopra M, Jasrotia RS, Tomar RS, et al. Transcriptomic signature of drought response in pearl millet (Pennisetum glaucum (L.) and development of web-genomic resources. Sci Rep. 2018;8(1):3382. http://doi. org/10.1038/s41598-018-21560-1

PMid:29467369

52. Rana S, Kanwar K. Assessment of genetic diversity in Aloe vera $\mathrm{L}$. among different provinces of HP. J Med Plant Res. 2017;5(3):348-54.

53. Ahl LI, Grace OM, Pedersen HL, Willats WG, Jørgensen B, Rønsted N. Analyses of Aloe polysaccharide using carbohydrate microarray profiling. J AOAC Int. 2018;101(6):1720-8. http://doi. org/10.5740/jaoacint.18-0120 PMid:29895348

54. Fu PP. Pyrrolizidine alkaloids: Metabolic activation pathways leading to liver tumor initiation. Chem Res Toxicol. 2017;30(1):8193. http://doi.org/10.1021/acs.chemrestox.6b00297 PMid:28092947

55. Banik S, Sharangi AB. Phytochemistry, health benefits and toxicological profile of Aloe. J Pharmacogn Phytochem. 2019;8(3):4499-506.

56. Khatun MM, Tanny T, Yesmin S, Salimullah MD, Alam I. Evaluation of genetic fidelity of in vitro-propagated Aloe vera plants using DNA-based markers. Sci Asia. 2018;44:87-91.

57. Wei L. Selection on synonymous mutations revealed by 1135 genomes of Arabidopsis thaliana. Evol Bioinform. 2020;16(1):1-16.

58. Wang Z, Huang C, Lv H, Zhang M, Li X. In silico analysis and high-risk pathogenic phenotype predictions of non-synonymous single nucleotide polymorphisms in human Crystallin beta A4 gene associated with congenital cataract. PLoS One. 2020;15(1):e0227859. pone.0227859 http://doi.org/10.1371/journal.

PMid:31935276 